\title{
LncRNA BANCR facilitates vascular smooth proliferation and migration through JNK pathway
}

\author{
He Li ${ }^{1}$, Xian Liu ${ }^{1}$, Lan Zhang ${ }^{1}$ and Xueqi Li $^{1}$ \\ ${ }^{1}$ Department of Cardiology, The Fourth Hospital of Harbin Medical University, Harbin, China
}

Correspondence to: Xueqi Li, email: ueqili@126.com

Keywords: atherosclerosis, vascular smooth muscle cell, IncRNAs, BANCR, JNK

Received: May 31, 2017

Accepted: September 08, 2017

Published: October 07, 2017

Copyright: Li et al. This is an open-access article distributed under the terms of the Creative Commons Attribution License 3.0 (CC BY 3.0 ), which permits unrestricted use, distribution, and reproduction in any medium, provided the original author and source are credited.

\section{ABSTRACT}

\begin{abstract}
Deregulated migration and proliferation of vascular smooth muscle cells (VSMCs) acts a crucial role in the pathogenesis of many cardiovascular diseases such as atherosclerosis, coronary heart disease and hypertension. Long noncoding RNAs (IncRNAs) play crucial functional roles in a lot of biological processes such as cell development, cell proliferation, differentiation and invasion. In our study, we demonstrated that the BANCR expression level was upregulated in the atherosclerotic plaques tissues compared to in the normal vessels tissues. TNF-a could emhance the VSMCs proliferation. The expression level of BANCR and p-JNK were upregulated and activated in the proliferating VSMCs. Overexpression of BANCR enhanced VSMCs proliferation and migration. Elevated expression of BANCR induced JNK activation, which can be decreased by the specific JNK inhibitor SP600125. We demonstrated that ectopic expression of BANCR increased the VSMCs proliferation and migration through activating JNK pathway. These data suggested that IncRNA BANCR acts a crucial role in the regulating VSMCs proliferation and migration partly by activating the JNK pathway.
\end{abstract}

\section{INTRODUCTION}

Vascular smooth muscle cells (VSMCs) are the major construction of the vasculature and act crucial roles in maintaining blood pressure and vessel tone [1-5]. Deregulated proliferation of VSMCs is a central factor in various cardiovascular diseases including hypertension, coronary heart disease and atherosclerosis [2, 6-9]. VSMCs proliferation and migration can be stimulated by a lot of cytokines and growth factors such as TNF- $\alpha$ and leptin, which act an important role in the development of these diseases [10-12]. However, the mechanism of how these moleculars modulate the VSMCs proliferation remains unclear.

Long noncoding RNAs (lncRNAs) are defined as RNAs with length more than 200 nucleotides with limited or without palpable protein-coding functions [13-18]. Recently, various studies have demonstrated that lncRNAs play important functional roles in biological processes such as cell proliferation, metastasis, development, differentiation, migration and invasion [19-24]. Notably, various lncRNAs were found to be deregulated in a lot of tumors including gastric cancer, colon cancer, hepatocellular carcinoma, gallbladder carcinoma and breast cancer [13-15, 25, 26]. BRAF-activated noncoding RNA (BANCR) is a 693-bp lncRNA firstly identified in melanoma cells $[27,28]$. Deregulated expression of BANCR was found in lung cancer, colorectal cancer, gastric cancer and bladder cancer [29-32]. BANCR modulated cell migration, invasion and proliferation and acted as a potential tumor suppressor or oncogene $[28,29,33,34]$. However, its expression, function and roles in VSMCs are unknown and need to be investigated.

In this study, we showed that the expression of BANCR was upregulated in the atherosclerotic plaques tissues compared to that in normal vessels tissues. The expression of BANCR and p-JNK were upregulated and activated in the proliferating VSMCs. Elevated expression of BANCR promoted VSMCs proliferation and migration. 


\section{RESULTS}

\section{BANCR expression was upregulated in atherosclerotic plaques tissues}

We first measured the BANCR expression in the atherosclerosis tissues. The expression of BANCR in normal vessels tissues and human atherosclerotic plaques tissues was shown in the Figure 1A. The expression level of BANCR was upregulated in atherosclerotic plaques tissues compared to in the normal vessels tissues (Figure 1B).

\section{BANCR expression was upregulated by TNF- $\alpha$ in the VSMCs}

We further measured the expression of BANCR in the proliferating VSMCs. We confirmed that TNF- $\alpha$ (50 $\mathrm{ng} / \mathrm{ml}$ ) promoted VSMCs proliferation (Figure 2A). As shown in the Figure 2B, the expression of BANCR was upregulated in the proliferating VSMCs (Figure 2B). In addition, the expression of $\mathrm{p}-\mathrm{JNK}$ was activated in the proliferating VSMCs (Figure 2C).

\section{BANCR promoted the VSMCs proliferation and migration}

To measure the functional role of BANCR in the VSMCs, we treated the VSMCs with pcDNA-BANCR. The expression of BANCR was significantly upregulated in the VSMCs after treated with pcDNA- BANCR (Figure 3A). Elevated expression of BANCR promoted VSMCs proliferation (Figure 3B). We also demonstrated that overexpression of BANCR increased cyclin D1 expression in the VSMCs (Figure 3C). Ectopic expression of BANCR promoted VSMCs migration (Figure 3D and 3E).

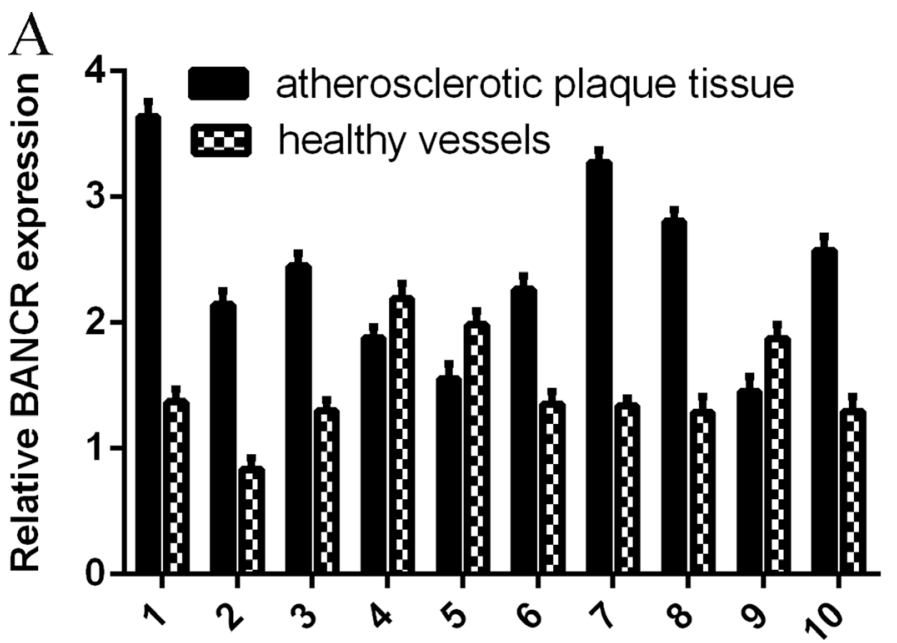

BANCR induced JNK signal pathway activation

As shown in the Figure 4A, the JNK was activated in the pcDNA-BANCR transfected VSMCs compared with control transfected cells. Moreover, this effect was inhibited by treated with SP600125, which was the inhibitor of the JNK (Figure 4B).

\section{BANCR promoted VSMCs proliferation and migration via regulating $\mathrm{JNK}$}

In order to detect the effect of JNK on the BANCRregulated cell migration and proliferation, the VSMCs that were treated with specific JNK inhibitor SP600125. The VSMCs proliferation was significantly decreased after treated with specific JNK inhibitor SP600125 (Figure 5A). In line with this, cyclin D1 expression was also suppressed in the VSMCs (Figure 5B). The BANCR-induced VSMCs migration was also decreased after treated with specific JNK inhibitor SP600125 (Figure 5C, 5D).

\section{DISCUSSION}

In this study, we showed that the expression level of BANCR was upregulated in the atherosclerotic plaques tissues compared to in the normal vessels tissues. We demonstrated that TNF- $\alpha$ promoted the VSMCs proliferation. The expression level of BANCR was upregulated and the expression of p-JNK was activated in the proliferating VSMCs. Elevated expression of BANCR enhanced the VSMCs proliferation and migration. Overexpression of BANCR can induce the JNK activation, which could be suppressed by the specific JNK inhibitor SP600125. We also demonstrated that ectopic expression of BANCR promoted VSMCs proliferation and migration by regulating JNK. These data suggested that lncRNA

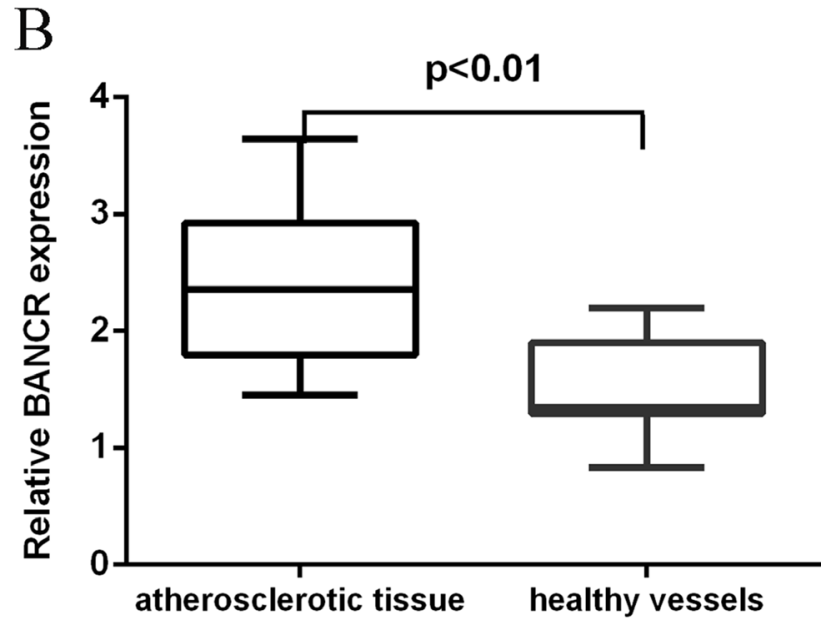

Figure 1: BANCR expression was upregulated in atherosclerotic plaques tissues. (A) The expression of BANCR in normal vessels tissues and human atherosclerotic plaques tissues was determined by qRT-PCR. (B) The expression level of BANCR was upregulated in atherosclerotic plaques tissues compared to in the normal vessels tissues. ${ }^{* * *} p<0.001$. 

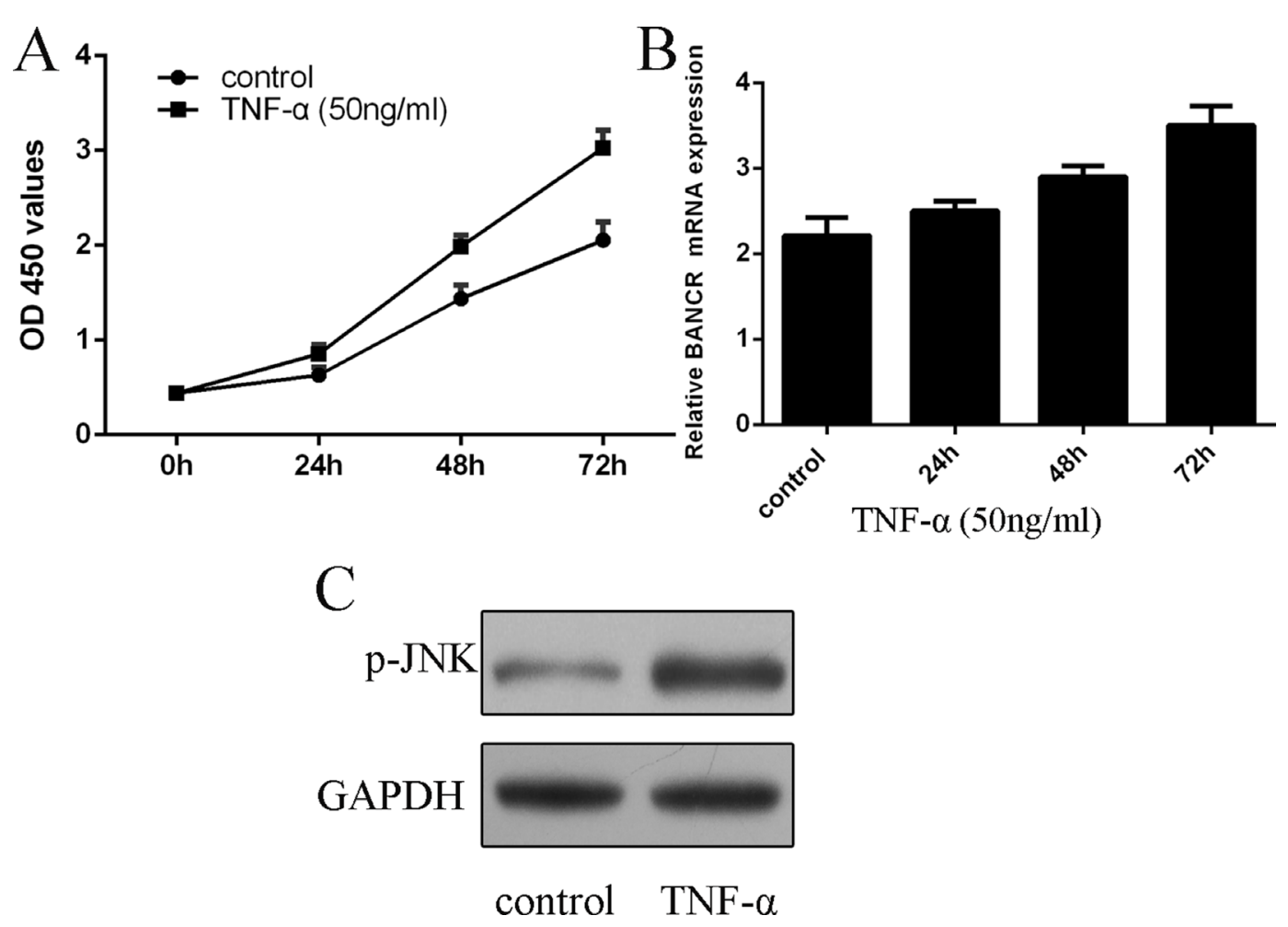

Figure 2: BANCR expression was upregulated by TNF- $\alpha$ in the VSMCs. (A) TNF- $\alpha$ (50 ng/ml) promoted VSMCs proliferation. (B) The expression of BANCR in the proliferating VSMCs was measured by qRT-PCR. (C) The expression of p-JNK was detected by western blot. ${ }^{*} p<0.05,{ }^{* *} p<0.01$ and ${ }^{* * *} p<0.001$.



$\mathrm{D}$

control
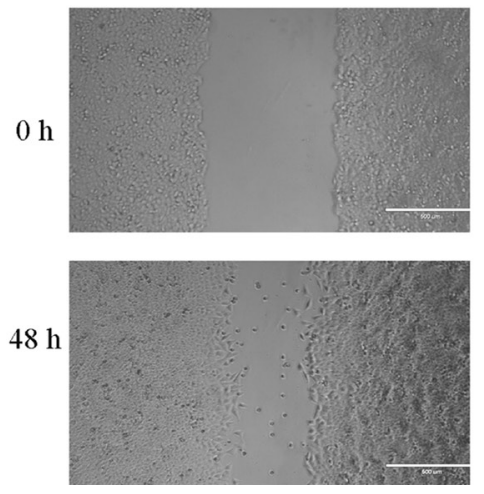
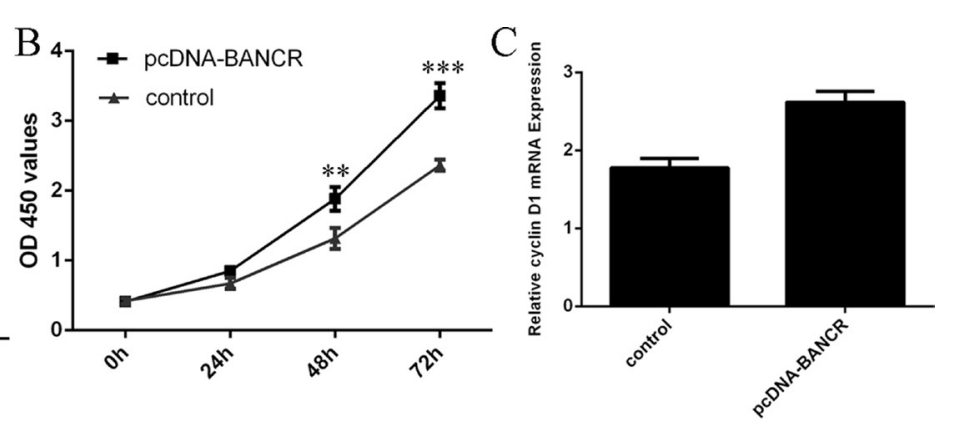

$\mathrm{E}$
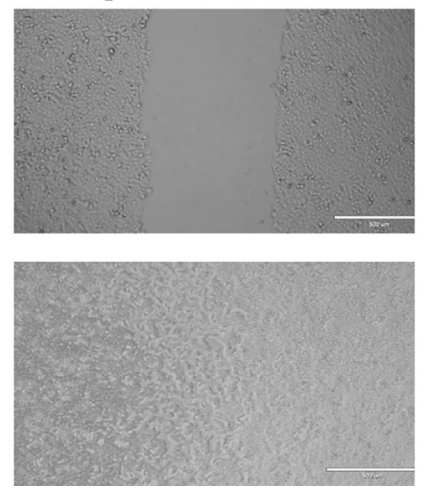

Figure 3: BANCR promoted the VSMCs proliferation and migration. (A) The expression of BANCR in the VSMCs after treated with pcDNA- BANCR was measured by qRT-PCR. (B) Elevated expression of BANCR promoted VSMCs proliferation. (C) Overexpression of BANCR increased cyclin D1 expression in the VSMCs. (D) Ectopic expression of BANCR promoted VSMCs migration. (E) The relative migration wound was shown. ${ }^{* *} p<0.01$ and ${ }^{* * *} p<0.001$. 


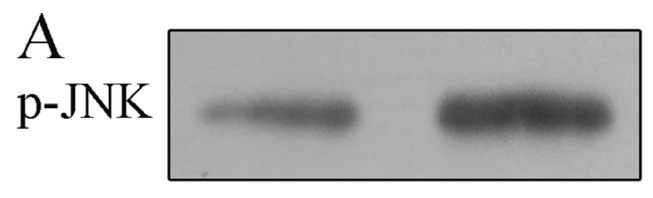

B
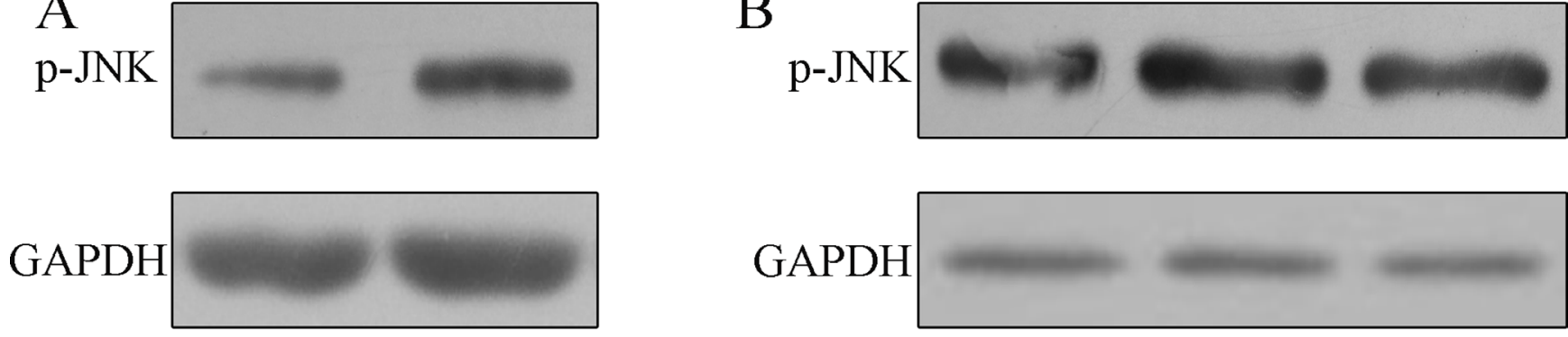

\section{control pcDNA-BANCR SP600125}

\section{pcDNA-BANCR}

Figure 4: BANCR induced JNK signal pathway activation. (A) The expression of p-JNK was detected by western blot. BANCR induced JNK signal pathway activation. (B) The expression of p-JNK in the VSMSs was detected by western blot.

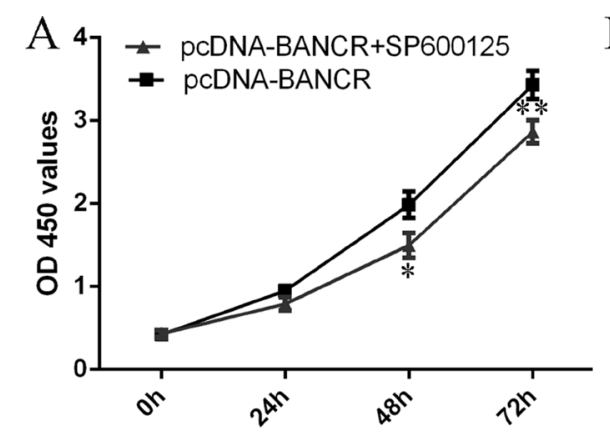

$\mathrm{C}$

$$
\text { pcDNA-BANCR+SB203580 }
$$
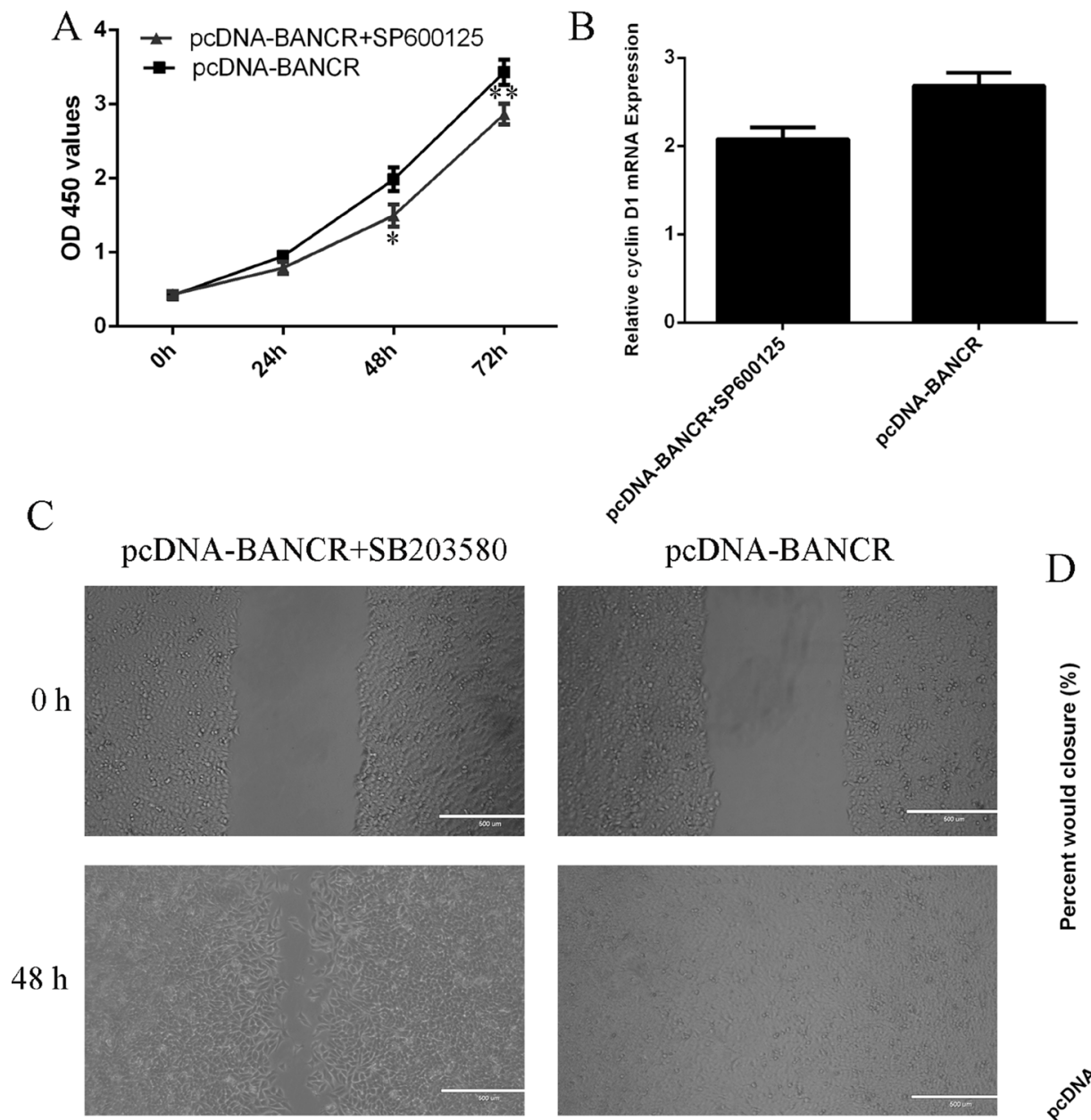

\section{D}
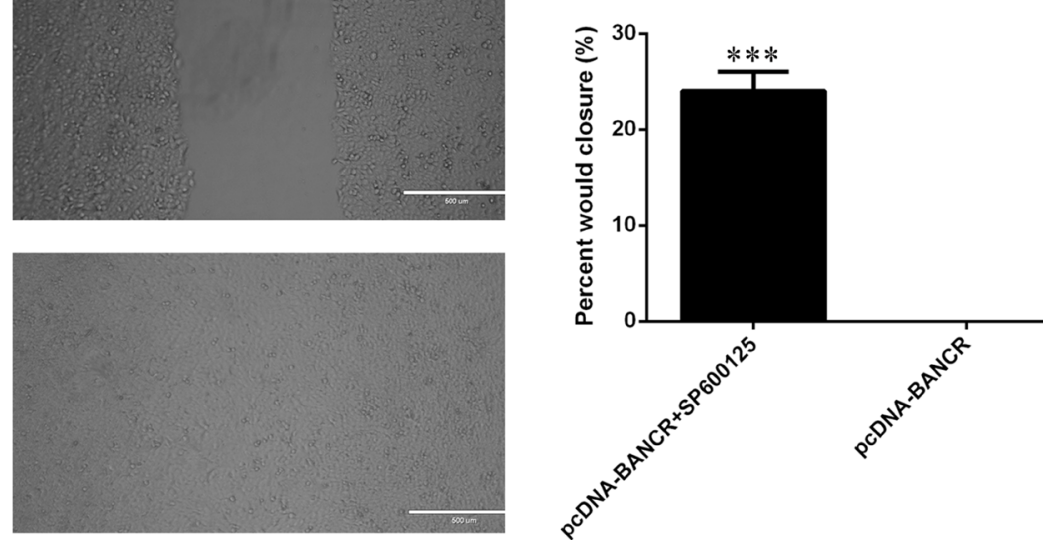

Figure 5: BANCR promoted VSMCs proliferation and migration via regulating JNK. (A) The VSMCs proliferation was significantly decreased after treated with specific JNK inhibitor SP600125. (B) The cyclin D1 expression was measured by qRT-PCR. (C) The BANCR-induced VSMCs migration was also decreased after treated with specific JNK inhibitor SP600125. (D) ${ }^{*} p<0.05,{ }^{* * *} p<0.01$ and ${ }^{* * *} p<0.001$. 
BANCR played an important role in regulating VSMCs proliferation and migration partly through activating the JNK pathway.

Previous evidences demonstrated that IncRNAs played a critical role in cardiovascular biology and disease [35-37]. LncRNAs can regulate the vessel function and growth and control phenotype of the smooth muscle cells [38-40]. For example, Wu et al. [41]. demonstrated that lincRNA-p21 regulated the VSMCs apoptosis and proliferation during atherosclerosis. They also showed that lincRNA-p21expression was downregulated in these patients with coronary artery disease. Zhao et al. [42]. showed that lncRNA HIF1a-AS1 was upregulated in this thoracoabdominal aorta aneurysm tissues and HIF1a-AS1 regulated the VSMCs proliferation and apoptosis. BANCR is a 693-bp lncRNA original identified in melanoma cells [27]. Increasing studies suggested that BANCR played an important role in the development of tumors $[28,31,32]$. For example, Li et al. [31]. showed that BANCR expression was upregulated in gastric cancer tissues and the expression of BANCR was correlated with the lymph node metastasis, tumor depth, clinical stage and distant metastasis. Zhang et al. [34]. demonstrated that overexpression of BANCR promoted the gastric cancer cell proliferation and suppressed the cell apoptosis through regulating the NF- $\kappa B 1$ expression. Li et al. [28]. showed that BANCR expression was upregulated in the malignant melanoma tissues and cell lines. Elevated expression of BANCR promoted the melanoma cell proliferation by activating ERK1/2 and JNK pathway. However, its expression and function roles in VSMCs are still unknown and need to be investigated. In our study, we firstly measured the BANCR expression in the atherosclerosis tissues. We demonstrated that the expression level of BANCR was upregulated in the atherosclerotic plaques tissues compared to in the normal vessels tissues. We also showed that TNF- $\alpha$ promoted VSMCs proliferation. The expression of BANCR was upregulated and the expression of p-JNK was activated in the proliferating VSMCs. Elevated expression of BANCR promoted the VSMCs proliferation and migration. These result suggested that BANCR played an important role in regulating VSMCs proliferation and migration.

MAPK pathway families act crucial roles in a large number of cell programs such as cell proliferation, differentiation, apoptosis, migration, and invasion [43-45]. Activation of Erk, JNK and p38 MAPK pathways can induce tumor cell development, differentiation, proliferation and other cell processes [46-48]. Previous studies also showed that JNK acted a critical role in VSMCs proliferation and migration [49-51]. Nagayama et al. [52]. demonstrated that Exendin-4 suppressed VSMCs migration and proliferation by Angiotensin II through inhibiting JNK and ERK1/2 signaling pathways. Zhang et al. [53]. also showed that overexpression of miR-92a suppressed the $\mathrm{H} 2 \mathrm{O} 2$-induced VSMC apoptosis through directly regulating the mitogen-activated protein kinase kinase 4 (MKK4) and JNK pathway. Recently, Jiang et al. [32]. showed that BANCR increased lung carcinoma migration and proliferation through MAPK pathways. $\mathrm{Li}$ et al. [28]. also demonstrated that BANCR promoted malignant melanoma cell proliferation through activating MAPK pathway. In line with this, we showed that overexpression of BANCR induced the JNK activation, which could be suppressed by the specific JNK inhibitor SP600125. We also demonstrated that ectopic expression of BANCR promoted VSMCs proliferation and migration by regulating JNK.

In conclusion, we demonstrated that the expression of BANCR was upregulated in the atherosclerotic plaques tissues compared to in the normal vessels tissues. The expression of BANCR was upregulated in the proliferating VSMCs. Elevated expression of BANCR promoted the VSMCs proliferation and migration through activating JNK pathway. These results suggested that IncRNA BANCR played an important role in regulating VSMCs proliferation and migration partly through activating the JNK pathway.

\section{MATERIALS AND METHODS}

\section{Cell culture and tissue samples}

Human atherosclerosis plaques samples in coronary artery patients and healthy vessels tissues were collected from the patients undergoing the surgery in our Departement. This study was approved by the Research Ethics Committee of the Fourth Hospital of Harbin Medical University. Written informed consent was obtained by all patients and this study aslo was complied with the Declaration of Helsinki. The VSMCs were purchased from Cascade Biologics (Portland) and kelpt in the recommended culture conditions. The pcDNABANCR and pcDNA-control was purchased from Genama (Shanghai, China) and transfected to the VSMCs by using the DharmaFECT1 Reagent (Dharmacon, TX, USA) according to the information.

\section{Real-time RT-PCR}

Total RNAs were isolated from cells by using TRIzol kit (Invitrogen, USA) following to the manufacturer's information. The qRT-PCR reaction was measured with the SYBR Green mix (Bio-Rad, CA, USA). The expression of GAPDH was monitored as the internal control. The real-time PCR was performed on the iQ-5 system (Bio-Rad) and the average $\mathrm{Ct}$ was used for calculations. The bellow primer was used: BANCR, Forward: 5'-ACAGGACTCCATGGCAAACG-3'; reverse: 5'-ATGAAGAAAGCCTGGTGCAGT-3'. GAPDH, Forward: 5'-GGGAGCCAAAAGGGTCAT-3'; reverse: 5'-GAGTCCTTCCACGATACCAA-3'. 


\section{Western blotting}

Total cellular protein was isolated by using lysis buffer and the protein concentration was measured by BCA assay (Pierce, Rockford, IL, USA). Equal proteins were separated on the $10 \%$ SDS and transferred to the PVDF membrane. After blocking with 5\% non-fat milk, the membrane was incubated with the primary antibodies (p-JNK and GAPDH, Sigma) and then incubated with horseradish peroxidase-conjugated secondary antibodies (Santa Cruz, CA).The protein signal was visualized by using the ECL chemiluminescence (Pierce).

\section{Cell proliferation and invasion}

For cell proliferation assay, the cell was seeded in the 96-well plate and cultured for 0, 24, 48, 72 hours. Cells were incubated with the MTT (3-(4, 5-dimethylthiazol2-yl)-2,5-diphenyltetrazolium bromide) for 1 hour. The absorbance OD was determined using the plate reader (PerkinElmer, MA, USA). For the invasion analysis, the insert was incubated with Matrigel (Sigma, St Louis, USA). Cell was cultured on the upper chamber with no-serum medium. $10 \%$ serum was added to the lower chamber and the cell was cultured for 48 hours. The cell which invaded into the lower surface was fixed with the paraformaldehyde and stained with crystal.

\section{Statistical analysis}

The result was expressed as the mean \pm standard deviation (SD). Statistical assay was done using the SPSS program ver. 17 (SPSS, Chicago, USA). The signicant difference between groups was determined using Student's $t$-test or ANOVA. $P<0.05$ was thought to be statistically significant.

\section{CONFLICTS OF INTEREST}

None.

\section{REFERENCES}

1. Kim MH, Ham O, Lee SY, Choi E, Lee CY, Park JH, Lee J, Seo HH, Seung M, Min PK, Hwang KC. MicroRNA-365 Inhibits the Proliferation of Vascular Smooth Muscle Cells by Targeting Cyclin D1. J Cell Biochem. 2014. https://doi. org/10.1002/jcb.24841.

2. Sun Y, Chen D, Cao L, Zhang R, Zhou J, Chen H, Li Y, Li M, Cao J, Wang Z. MiR-490-3p modulates the proliferation of vascular smooth muscle cells induced by ox-LDL through targeting PAPP-A. Cardiovasc Res. 2013; 100:272-9. https://doi.org/10.1093/cvr/cvt172.

3. Li P, Zhu N, Yi B, Wang N, Chen M, You X, Zhao X, Solomides CC, Qin Y, Sun J. MicroRNA-663 regulates human vascular smooth muscle cell phenotypic switch and vascular neointimal formation. Circ Res. 2013; 113:1117-27. https://doi.org/10.1161/CIRCRESAHA.113.301306.

4. Kim S, Kang H. miR-15b induced by platelet-derived growth factor signaling is required for vascular smooth muscle cell proliferation. BMB Rep. 2013; 46:550-4.

5. Choe N, Kwon JS, Kim JR, Eom GH, Kim Y, Nam KI, Ahn Y, Kee HJ, Kook H. The microRNA miR-132 targets Lrrfip1 to block vascular smooth muscle cell proliferation and neointimal hyperplasia. Atherosclerosis. 2013; 229:348-55. https://doi.org/10.1016/j.atherosclerosis.2013.05.009.

6. Yu X, Li Z, Chen G, Wu WK. MicroRNA-10b Induces Vascular Muscle Cell Proliferation Through Akt Pathway by Targeting TIP30. Curr Vasc Pharmacol. 2015; 13:679-86.

7. Song L, Duan P, Guo P, Li D, Li S, Xu Y, Zhou Q. Downregulation of miR-223 and miR-153 mediates mechanical stretch-stimulated proliferation of venous smooth muscle cells via activation of the insulin-like growth factor-1 receptor. Arch Biochem Biophys. 2012; 528:204-11. https://doi.org/10.1016/j.abb.2012.08.015.

8. Yu ML, Wang JF, Wang GK, You XH, Zhao XX, Jing Q, Qin YW. Vascular smooth muscle cell proliferation is influenced by let-7d microRNA and its interaction with KRAS. Circ J. 2011; 75:703-9.

9. Sun SG, Zheng B, Han M, Fang XM, Li HX, Miao SB, Su M, Han Y, Shi HJ, Wen JK. miR-146a and Kruppel-like factor 4 form a feedback loop to participate in vascular smooth muscle cell proliferation. EMBO Rep. 2011; 12:56-62. https://doi.org/10.1038/embor.2010.172.

10. Meng L, Xu W, Guo L, Ning W, Zeng X. Paeonol Inhibits the Proliferation, Invasion, and Inflammatory Reaction Induced by TNF-alpha in Vascular Smooth Muscle Cells. Cell Biochem Biophys. 2015; 73:495-503. https://doi. org/10.1007/s12013-015-0686-5.

11. Liu GY, Liang QH, Cui RR, Liu Y, Wu SS, Shan PF, Yuan LQ, Liao EY. Leptin Promotes the Osteoblastic Differentiation of Vascular Smooth Muscle Cells From Female Mice by Increasing RANKL Expression. Endocrinology. 2014; 155:558-67. https://doi.org/10.1210/en.2013-1298.

12. Aghagolzadeh $\mathrm{P}$, Bachtler M, Bijarnia R, Jackson C, Smith ER, Odermatt A, Radpour R, Pasch A. Calcification of vascular smooth muscle cells is induced by secondary calciprotein particles and enhanced by tumor necrosis factor-alpha. Atherosclerosis. 2016; 251:404-14. https:// doi.org/10.1016/j.atherosclerosis.2016.05.044.

13. Ma MZ, Chu BF, Zhang Y, Weng MZ, Qin YY, Gong W, Quan ZW. Long non-coding RNA CCAT1 promotes gallbladder cancer development via negative modulation of miRNA-218-5p. Cell Death Dis. 2015; 6:e1583. https:// doi.org/10.1038/cddis.2014.541.

14. Deng L, Yang SB, Xu FF, Zhang JH. Long noncoding RNA CCAT1 promotes hepatocellular carcinoma progression by functioning as let-7 sponge. J Exp Clin Cancer Res. 2015; 34:18. https://doi.org/10.1186/s13046-015-0136-7. 
15. Zhang Y, Ma M, Liu W, Ding W, Yu H. Enhanced expression of long noncoding RNA CARLo-5 is associated with the development of gastric cancer. Int J Clin Exp Pathol. 2014; 7:8471-9.

16. Xu ZY, Yu QM, Du YA, Yang LT, Dong RZ, Huang L, Yu PF, Cheng XD. Knockdown of long non-coding RNA HOTAIR suppresses tumor invasion and reverses epithelial-mesenchymal transition in gastric cancer. Int J Biol Sci. 2013; 9:587-97. https://doi.org/10.7150/ ijbs.6339.

17. He Y, Meng XM, Huang C, Wu BM, Zhang L, Lv XW, Li J. Long noncoding RNAs: Novel insights into hepatocelluar carcinoma. Cancer Lett. 2014; 344:20-7. https://doi.org/10.1016/j.canlet.2013.10.021.

18. He X, Bao W, Li X, Chen Z, Che Q, Wang H, Wan XP. The long non-coding RNA HOTAIR is upregulated in endometrial carcinoma and correlates with poor prognosis. Int J Mol Med. 2014; 33:325-32. https://doi.org/10.3892/ ijmm.2013.1570.

19. Tang L, Zhang W, Su B, Yu B. Long noncoding RNA HOTAIR is associated with motility, invasion, and metastatic potential of metastatic melanoma. Biomed Res Int. 2013; 2013:251098. https://doi. org/10.1155/2013/251098.

20. Zhu H, Zhou X, Chang H, Li H, Liu F, Ma C, Lu J. CCAT1 promotes hepatocellular carcinoma cell proliferation and invasion. Int J Clin Exp Pathol. 2015; 8:5427-34.

21. Pickard MR, Mourtada-Maarabouni M, Williams GT. Long non-coding RNA GAS5 regulates apoptosis in prostate cancer cell lines. Biochim Biophys Acta. 2013; 1832:161323. https://doi.org/10.1016/j.bbadis.2013.05.005.

22. Ono H, Motoi N, Nagano H, Miyauchi E, Ushijima M, Matsuura M, Okumura S, Nishio M, Hirose T, Inase N, Ishikawa Y. Long noncoding RNA HOTAIR is relevant to cellular proliferation, invasiveness, and clinical relapse in small-cell lung cancer. Cancer Med. 2014. https://doi. org/10.1002/cam4.220.

23. Zhu H, Li X, Song Y, Zhang P, Xiao Y, Xing Y. Long noncoding RNA ANRIL is up-regulated in bladder cancer and regulates bladder cancer cell proliferation and apoptosis through the intrinsic pathway. Biochem Biophys Res Commun. 2015; 467:223-8. https://doi.org/10.1016/j. bbrc.2015.10.002.

24. Naemura M, Murasaki C, Inoue Y, Okamoto H, Kotake Y. Long Noncoding RNA ANRIL Regulates Proliferation of Non-small Cell Lung Cancer and Cervical Cancer Cells. Anticancer Res. 2015; 35:5377-82.

25. McCleland ML, Mesh K, Lorenzana E, Chopra VS, Segal E, Watanabe C, Haley B, Mayba O, Yaylaoglu M, Gnad F, Firestein R. CCAT1 is an enhancer-templated RNA that predicts BET sensitivity in colorectal cancer. J Clin Invest. 2016. https://doi.org/10.1172/JCI83265.

26. Zhang XF, Liu T, Li Y, Li S. Overexpression of long non-coding RNA CCAT1 is a novel biomarker of poor prognosis in patients with breast cancer. Int J Clin Exp Pathol. 2015; 8:9440-5.

27. Flockhart RJ, Webster DE, Qu K, Mascarenhas N, Kovalski J, Kretz M, Khavari PA. BRAFV600E remodels the melanocyte transcriptome and induces BANCR to regulate melanoma cell migration. Genome Res. 2012; 22:1006-14. https://doi.org/10.1101/gr.140061.112.

28. Li R, Zhang L, Jia L, Duan Y, Li Y, Bao L, Sha N. Long non-coding RNA BANCR promotes proliferation in malignant melanoma by regulating MAPK pathway activation. PLoS One. 2014; 9:e100893. https://doi. org/10.1371/journal.pone.0100893.

29. Shi Y, Liu Y, Wang J, Jie D, Yun T, Li W, Yan L, Wang K, Feng J. Downregulated Long Noncoding RNA BANCR Promotes the Proliferation of Colorectal Cancer Cells via Downregualtion of p21 Expression. PLoS One. 2015; 10:e0122679. https://doi.org/10.1371/journal. pone.0122679.

30. He A, Liu Y, Chen Z, Li J, Chen M, Liu L, Liao X, Lv Z, Zhan Y, Zhuang C, Lin J, Huang W, Mei H. Overexpression of long noncoding RNA BANCR inhibits malignant phenotypes of human bladder cancer. J Exp Clin Cancer Res. 2016; 35:125. https://doi.org/10.1186/s13046016-0397-9.

31. Li L, Zhang L, Zhang Y, Zhou F. Increased expression of LncRNA BANCR is associated with clinical progression and poor prognosis in gastric cancer. Biomed Pharmacother. 2015; 72:109-12. https://doi.org/10.1016/j. biopha.2015.04.007.

32. Jiang W, Zhang D, Xu B, Wu Z, Liu S, Zhang L, Tian Y, Han X, Tian D. Long non-coding RNA BANCR promotes proliferation and migration of lung carcinoma via MAPK pathways. Biomed Pharmacother. 2015; 69:90-5. https:// doi.org/10.1016/j.biopha.2014.11.027.

33. Su S, Gao J, Wang T, Wang J, Li H, Wang Z. Long noncoding RNA BANCR regulates growth and metastasis and is associated with poor prognosis in retinoblastoma. Tumour Biol. 2015; 36:7205-11. https://doi.org/10.1007/ s13277-015-3413-3.

34. Zhang ZX, Liu ZQ, Jiang B, Lu XY, Ning XF, Yuan CT, Wang AL. BRAF activated non-coding RNA (BANCR) promoting gastric cancer cells proliferation via regulation of NF-kappaB1. Biochem Biophys Res Commun. 2015; 465:225-31. https://doi.org/10.1016/j.bbrc.2015.07.158.

35. Wang Z, Zhang XJ, Ji YX, Zhang P, Deng KQ, Gong J, Ren S, Wang X, Chen I, Wang H, Gao C, Yokota T, Ang YS, et al. The long noncoding RNA Chaer defines an epigenetic checkpoint in cardiac hypertrophy. Nat Med. 2016; 22:1131-9. https://doi.org/10.1038/nm.4179.

36. Huang C, Hu YW, Zhao JJ, Ma X, Zhang Y, Guo FX, Kang CM, Lu JB, Xiu JC, Sha YH, Gao JJ, Wang YC, Li P, et al. Long Non-Coding RNA HOXC-AS1 Suppresses Ox-LDLInduced Cholesterol Accumulation Through Promoting HOXC6 Expression in THP-1 Macrophages. DNA Cell Biol. 2016. https://doi.org/10.1089/dna.2016.3422. 
37. Huang ZP, Ding Y, Chen J, Wu G, Kataoka M, Hu Y, Yang JH, Liu J, Drakos SG, Selzman CH, Kyselovic J, Qu LH, Dos Remedios CG, et al. Long non-coding RNAs link extracellular matrix gene expression to ischemic cardiomyopathy. Cardiovasc Res. 2016. https://doi. org/10.1093/cvr/cvw201.

38. Zhang XY, Zhang LX, Tian CJ, Tang XY, Zhao LM, Guo YL, Cheng DJ, Chen XL, Ma LJ, Chen ZC. LncRNAs BCYRN1 promoted the proliferation and migration of rat airway smooth muscle cells in asthma via upregulating the expression of transient receptor potential 1. Am J Transl Res. 2016; 8:3409-18.

39. Yang S, Yao H, Li M, Li H, Wang F. Long Non-Coding RNA MALAT1 Mediates Transforming Growth Factor Beta1-Induced Epithelial-Mesenchymal Transition of Retinal Pigment Epithelial Cells. PLoS One. 2016; 11:e0152687. https://doi.org/10.1371/journal. pone. 0152687 .

40. He Q, Tan J, Yu B, Shi W, Liang K. Long noncoding RNA HIF1A-AS1A reduces apoptosis of vascular smooth muscle cells: implications for the pathogenesis of thoracoabdominal aorta aneurysm. Pharmazie. 2015; 70:310-5.

41. Wu G, Cai J, Han Y, Chen J, Huang ZP, Chen C, Cai Y, Huang H, Yang Y, Liu Y, Xu Z, He D, Zhang X, et al. LincRNA-p21 regulates neointima formation, vascular smooth muscle cell proliferation, apoptosis, and atherosclerosis by enhancing p53 activity. Circulation. 2014; 130:1452-65. https://doi.org/10.1161/ Circulationaha.114.011675.

42. Zhao Y, Feng G, Wang Y, Yue Y, Zhao W. Regulation of apoptosis by long non-coding RNA HIF1A-AS1 in VSMCs: implications for TAA pathogenesis. Int J Clin Exp Pathol. 2014; 7:7643-52.

43. Lake D, Correa SA, Muller J. Negative feedback regulation of the ERK1/2 MAPK pathway. Cell Mol Life Sci. 2016; 73:4397-413. https://doi.org/10.1007/s00018-016-2297-8.

44. Segales J, Perdiguero E, Munoz-Canoves P. Regulation of Muscle Stem Cell Functions: A Focus on the p38 MAPK Signaling Pathway. Front Cell Dev Biol. 2016; 4:91. https://doi.org/10.3389/fcell.2016.00091.

45. Zhou X, Naguro I, Ichijo H, Watanabe K. Mitogenactivated protein kinases as key players in osmotic stress signaling. Biochim Biophys Acta. 2016; 1860:2037-52. https://doi.org/10.1016/j.bbagen.2016.05.032.
46. Pandey V, Bhaskara VK, Babu PP. Implications of mitogen-activated protein kinase signaling in glioma. $\mathrm{J}$ Neurosci Res. 2016; 94:114-27. https://doi.org/10.1002/ jnr.23687.

47. Peti W, Page R. Molecular basis of MAP kinase regulation. Protein Sci. 2013; 22:1698-710. https://doi.org/10.1002/ pro.2374.

48. Osaki LH, Gama P. MAPKs and signal transduction in the control of gastrointestinal epithelial cell proliferation and differentiation. Int J Mol Sci. 2013; 14:10143-61. https:// doi.org/10.3390/ijms140510143.

49. Wu Y, Zhou J, Wang H, Gao Q, Wang L, Zhao Q, Liu P, Gao S, Wen W, Zhang W, Liu Y, Yuan Z. The activation of p38 MAPK limits the abnormal proliferation of vascular smooth muscle cells induced by high sodium concentrations. Int J Mol Med. 2016; 37:74-82. https:// doi.org/10.3892/ijmm.2015.2394.

50. Youreva V, Srivastava AK. Early Growth Response Protein-1 Expression by Insulin-Like Growth Factor-1 Requires ROS-Dependent Activation of ERK1/2 and PKB Pathways in Vascular Smooth Muscle Cells. J Cell Biochem. 2016; 117:152-62. https://doi.org/10.1002/ jcb.25260.

51. Du CQ, Liu XW, Zeng GZ, Jin HF, Tang LJ. Inhibition of farnesyl pyrophosphate synthase attenuates angiotensin IIinduced fibrotic responses in vascular smooth muscle cells. Int J Mol Med. 2015; 35:1767-72. https://doi.org/10.3892/ ijmm.2015.2166.

52. Nagayama K, Kyotani Y, Zhao J, Ito S, Ozawa K, Bolstad FA, Yoshizumi M. Exendin-4 Prevents Vascular Smooth Muscle Cell Proliferation and Migration by Angiotensin II via the Inhibition of ERK1/2 and JNK Signaling Pathways. PLoS One. 2015; 10:e0137960. https://doi.org/10.1371/ journal.pone.0137960.

53. Zhang L, Zhou M, Wang Y, Huang W, Qin G, Weintraub NL, Tang Y. miR-92a inhibits vascular smooth muscle cell apoptosis: role of the MKK4-JNK pathway. Apoptosis. 2014; 19:975-83. https://doi.org/10.1007/s10495-0140987-y. 